\title{
From intersectionality to interference: Feminist onto-epistemological reflections on the politics of representation ${ }^{\text {is }}$
}

\author{
Evelien Geerts, Iris van der Tuin* \\ Graduate Gender Programme, Utrecht University, The Netherlands
}

\section{A R T I C L E I N F O}

Available online 2 September 2013

\begin{abstract}
S Y N O P S I S
This article reviews the debate on 'intersectionality' as the dominant approach in gender studies, with an emphasis on the politics of representation. The debate on intersectionality officially began in the late 1980s, though the approach can be traced back to the institutionalization of women's studies in the 1970s and the feminist movement of the 1960s. Black and lesbian feminists have long advocated hyphenated identities to be the backbone of feminist thought. But in recent years, intersectionality has sustained criticism from numerous angles within gender studies, ranging from feminist philosophy to applied political research. This article will use the theorization of 'interference' as a searchlight to produce an overview of this interdisciplinary debate, culminating in our affirmative answer to the question: should we move from intersectionality to interference? Our answer is based on onto-epistemological reflections, i.e., reflections in which being and knowing are always already entangled.
\end{abstract}

(c) 2013 Elsevier Ltd. All rights reserved.

\section{Introduction: intersectionality under fire}

'Intersectionality' - or the idea that subjects are situated in frameworks of multiple, interacting forms of oppression and privilege through socially constructed categories such as gender and 'race'/ethnicity - has become a central paradigm in feminist theory (see e.g., Cho, Crenshaw, \& McCall, 2013; Franken, Woodward, Cabó, \& Bagilhole, 2009; Lutz, Theresa Herrera Vivar, \& Supik, 2011; Oleksy, 2011). It is seen as "the most important theoretical contribution that women's studies, in conjunction with related fields, has made so far" (McCall, 2005: 1771) and a prescient tool to further the inclusive political project of feminism (Wekker, 2004). Nevertheless, intersectionality's success appears to have much to do with its "vagueness and open-endedness" (Davis, 2008:

\footnotetext{
is The authors first of all wish to thank the editor of this special issue of Women's Studies International Forum, Liza Mügge, for her kind invitation and constructive, enthusiastic response to our piece. We also wish to thank the two anonymous reviewers for their valuable feedback and insightful comments, and Takeo David Hymans for his editorial suggestions.

* Corresponding author at: Muntstraat 2a, 3512EV Utrecht, the Netherlands.
}

69). We begin with its terminology. While most authors have used the metaphor of an intersection or crossroad to think about the inter-relatedness of social categories and their multi-facetted impact on the subject (see e.g., Crenshaw, 1989, 1991; Wekker, 2002), others have preferred to work with $a$ matrix of domination (Collins, 1990/2009; Harding, 1995), the notion of transversal politics (Collins, 1990/2009; Yuval-Davis, 1999), and reconceptualizations of intersectionality as either a performative process (Staunæs, 2003) or a Deleuzian rhizome with crisscrossing roots that depict the multi-directionality of oppression (Lykke, 2011). The latter are all attempts to change the very basis of intersectionality - its conceptual attachment to social constructivism - which has been critiqued for two, seemingly opposite, reasons. This article will explain these critiques and continue this critical line of reasoning through a so-called 'onto-epistemological' analysis of the politics of representation (Barad et al., 2007).

Naomi Zack's philosophical critique of intersectional thought searches for a non-exclusive commonality between women owing to intersectionality's "ontological indeterminacy" (Zack, 2007: 199). Since an intersectional model could 
lead to an endless proliferation of identities composed of ceaselessly intersecting categories, a philosophical defense of the latter would have to be based upon moral rather than theoretical grounds. Theoretically, intersectionality's politics of representation leads to relativism. On the other end of the spectrum, scholars from critical race studies and feminist post-humanism have criticized intersectionality for being exclusivist. By portraying black women as the "quintessential intersectional subjects" (Nash, 2008: 1), and by leaving the experiences of ( partially and fully) privileged women out of the picture, black women are once again represented monolithically. The critique of exclusivity has also been developed on a more ontological level. Maneesha Deckha (2008), for instance, has argued that the intersectional paradigm is rooted in anthropomorphic assumptions which have prevented scholars from considering the differences between human and non-human species. The exclusivism of intersectionality stems from its epistemic bias: intersectional thinkers have accentuated the epistemological aspects of social categories (i.e., how is race known?) to such an extent that they have neglected the ontological and material, bodily aspects of, for instance, racialized subjects (Saldanha, 2006: 9). Counter-intuitively, ontological reflections broaden intersectionality's theoretical reach, whereas the foregoing epistemic bias is caused by feminism's anxiety about the body in particular, stemming from the naturalization of women and minorities. Indeed, intersectional theories arose in the intellectual climate of feminist poststructuralism and postmodernism - schools of thought that focused on social constructivism and discursivity and which are currently being criticized for their antimaterialist attitudes. The latter set of reflections can be called onto-epistemological.

While some scholars criticize intersectionality for being too rooted in modern nature/culture and human/non-human binaries, others engage in critical and affirmative dialogues with intersectional thought within their own disciplines (see also Mügge \& de Jong, 2013). One such scholar is political scientist Mieke Verloo, who argues that the European Union currently lacks policies that take multiple and diverse inequalities into account. In response she has developed her own Crenshaw-inspired model of political intersectionality, political mainstreaming. Verloo has a dynamic understanding of inequalities, and like the critics referred to above, does not neglect the influence that power structures have on subjects and social categories (see Verloo, 2006: 224). In doing so she introduces the concept of interference, which refers to "the convergence of waves (light/sound/water), which results in patterns of intensification or higher intensity, while there are also places where the waves cancel each other or are weakened" (Verloo, 2009: 10; our translation). Intersectionality, then, should be limited to those interference patterns that "lead to an increase or specification of inequality" (Verloo, 2009: 10). Verloo argues that though structural inequalities exist, we cannot assume to know their inner workings and precise effects. Not only does intersectionality take oppression to the nth power for granted (i.e., it quantifies power relations along the lines of second-wave feminism's double oppression); it has too many presuppositions about the ontology of power (it is a pure potestas or restriction, whereas Michel Foucault also pointed to the potential, or the productive side of power (Braidotti, 1994/ 2011)). Verloo wants to be able to show that a particular policy can have a negative impact on those whom we deem universally powerful (white, heterosexual, middle-class, ablebodied women).

This article follows Verloo by asking whether we should move from the paradigm of intersectionality in contemporary gender studies to the realm of interference. Inspired by the so-called 'feminist new materialist' critique of social constructivism, which allows us to focus on the ontological dimension of intersectional research, we first present a genealogy of intersectional thought and its epistemological premises (see also Carbin \& Edenheim, 2013). We then reflect on how intersectionality's identity politics (or its politics of representation) is related to representationalism (i.e., the epistemological backbone of essentialism and constructivism alike). This enables us to evaluate the promises of interference, for which we turn to feminist new materialist Karen Barad, the feminist philosopher-physicist who has proposed a comprehensive theory of interference or 'diffraction' (Barad et al., 2007). In other words, onto-epistemology and interference are intricately linked; they stem from the same paradigm.

\section{The genealogy of intersectionality}

Although the debate on intersectionality officially took off in the late 1980s, black and lesbian feminists have long tried to open up the category of women through hyphenated identities. This, however, does not mean that intersectionality theorists in the 1980s and 1990s simply recycled the ideas of black feminist groups, as Jennifer Nash has claimed (Nash, $2008,9)$. Although we wish to refrain from reading the intersectionality debate teleologically, a genealogical overview shows that intersectional theories have their origins in black feminist thought, where they were developed as critiques of the exclusivity and solipsism of feminist theories that solely focused on the experiences of white, middleclass women (Crenshaw, 1989; hooks, 1984). After this initial critical phase, intersectionality since the early 1990s has steadily become part of the feminist canon.

In this part of our essay, we show that intersectional theory has integrated much of the epistemological content of feminist standpoint theory, which is why it has been so easily mainstreamed within the feminist theoretical landscape. Intersectionality's epistemological premises can be best demonstrated by first looking at Sandra Harding's famous classification of feminist epistemologies in (Harding, 1986).

Intersectional theory and the feminist standpoint: Harding and black feminist thought

In Science Question, Harding claims that there are three possible feminist answers to what should be seen as knowledge and on what kinds of experience knowledge should be based: namely feminist empiricism, the feminist standpoint, and feminist postmodernism. Empiricism sees scientific facts as neutrally mirroring reality outside the academy; its ground structure hints at positivism (i.e., only trusting verification by sense data). But feminist empiricism also argues that women/ feminists as a group produce more objective knowledge than men/non-feminists as individuals or as a group, and that social liberation movements increase the level of objectivity by 
acknowledging the role of context in discovery. Not only feminist standpoint theories therefore argue that "communities [of people] and not primarily individuals produce knowledge" (Harding, 1993: 65). Nevertheless, feminist empiricism mainly problematized bad science (Harding, 1986: 24-5). Feminist standpoint theory was the revolutionary branch of feminist epistemology with its "stronger standards for maximizing objectivity" (Harding, 1993: 69) - its call for strong reflexivity placed "the subject of knowledge $[. .$.$] on the same critical, causal plane as the$ objects of knowledge" (Harding, 1986: 69). Feminist standpoint theory thus problematizes science-as-usual and invents a science by and for women.

Science Question then presented feminist postmodernism as the advocate of basing feminist knowledge claims on the fractured identities of "a Black-feminist, a socialist-feminist, a lesbian-feminist, and so forth" (Harding, 1986: 193). Feminist postmodernism works differently from feminist standpoint theory as "the goal of telling "one true story" is abandoned in favor of "the permanent partiality of feminist inquiry” (Harding, 1986: 194). The problematic universalisms of feminist empiricism and feminist standpoint theory were said to be resolved in feminist postmodernism's focus on diversity rather than equality or difference. Following Donna Haraway's (1988) famous critique that the universalisms of feminist empiricism and the feminist standpoint, on the one hand, and the potential relativism of feminist postmodernism, on the other, were unreal binaries, Harding (1993: 66) stuck to the fact that "lesbian, poor, and racially marginalized women are all women." Seemingly unconcerned by the naturalizing effects of universalism, Harding allowed feminist standpoint to incorporate feminist postmodernism's concerns.

Some of the key points of feminist standpoint theory - that social relationships are power-laden and often conflictual, and that social disadvantage translates into epistemological advantage (see Harding, 1986: 26, 1993: 53-56, 1995: 341-344) were already central to intersectionality's forerunners, including the Black liberationist Combahee River Collective. The latter focused on the "personal experiences of individual Black women's lives” (Combahee River Collective, 1977/1982: 221) and anticipated intersectionality's emphasis on how different forms of oppressions are experienced simultaneously. Feminist intersectionality theorists such as Kimberlé Crenshaw, bell hooks, Patricia Hill Collins, and Audre Lorde then continued this line of thought in the mid-1980s and early 1990s. Their inscription in feminist standpoint theory allowed intersectionality to make its first inroads into academic feminism.

Crenshaw is said to have coined the term intersectionality. Her landmark essay "Demarginalizing the Intersection of Race and Sex" (Crenshaw, 1989) analyzes some paradigmatic American court cases on the discrimination of Black women. Crenshaw attacks traditional feminist theory and antiracist policy discourses for being epistemologically flawed: instead of focusing on the totality of "Black women's experience" (Combahee River Collective, 1977/1982: 139), these theoretical models fragmented Black female subjectivity by focusing either on gender oppression or on blackness. The idea of Black women being discriminated against twice, and simultaneously, remains unnoticed in theories that work within a single-axis framework. As Crenshaw interpreted this 'either-or' approach:

Black women are regarded either as too much like women or Blacks and the compounded nature of their experience is absorbed into the collective experiences of either group or as too different, in which case Black women's Blackness or femaleness sometimes has placed their needs and perspectives at the margins of the feminist and Black liberationist agendas (Crenshaw, 1989: 150).

Here we face a situation of either universalism (a common humanity) or marginalization (essential racial/sexual difference). For Crenshaw, feminist universalist theories are unable to identify female blackness, while universalist theories of race are unable to specify Black femaleness. Put differently, female Blackness is subsumed under sex and Black femaleness under 'race.' Either way, the effect for Crenshaw is the same: "Black women [have been treated] in ways that deny both the unique compoundedness of their situation and the centrality of their experiences to the larger classes of women and Blacks" (Crenshaw, 1989: 150). Black female subjects thus remain under-represented, even unrepresented. Crenshaw hopes to correct this epistemological wrongdoing through her intersectional approach, which resists fragmenting Black women into either sexualized or racialized subjects: "the intersectional experience is greater than the sum of racism and sexism" (Crenshaw, 1989: 140). Crenshaw later continued her project by conceptualizing intersectionality as a structural, political, representational, and hence multi-layered phenomenon (Crenshaw, 1991).

Crenshaw as well as hooks, Lorde and especially Collins placed Black women's “lived experience" (Collins, 1990/2009: 275-279; hooks, 1984: 15) at the center of analysis. It is their "subjugated knowledge" (Collins, 1990/2009: 269) that allows Black women to see through, for example, events in court. The above thinkers have thus not only followed in Black feminism's footsteps, but also developed the core of feminist standpoint theory that basically begins with the motto 'the personal is political' and focuses on the feminist-Marxist model of dialectical knowledge production. They also plead for approaching and representing Black female subjects in a holistic, i.e., non-fragmented (see for instance Lorde et al., 1997: 378) and non-additive manner (see also Spelman, 1988) - a typical feature of feminist standpoint theory as it tries to move away from the standard liberal atomist philosophy that a subject equals the sum of her/his atom-like aspects of identity.

Intersectional theorists such as Collins respect the multitude of experiences and the "different patterns of experiential knowledge" (Collins, 1990/2009: 30) of Black women. This anti-essentialist stance leads to a straightforward rejection of identity politics as it "conflates or ignores intragroup differences" (Crenshaw, 1991: 1242). Unlike traditional liberatory politics or antiracist discourses, intersectional theory starts from the idea that there are "multiple dimensions of identity" (Crenshaw, 1991: 1245) to be considered when dealing with Black women's experiences. It is this focus on a non-essentialist group politics, or what Collins has labeled transversal politics (Collins, 1990/2009: 264-268) - i.e., a dialogical, anti-binary kind of group politics that sees the group as a fluid entity, composed of subjects that have certain (but not all) categories 
in common - that has made intersectional theory analogous to feminist postmodern theories from the early 1990s that radicalized standpoint theoretical attempts to embrace antiessentialism and anti-universalism. While the analysis of 'difference' became the focal point of feminist theoretical landscapes in the 1990s (see Felski, 1997), the similarities between feminist postmodernism and intersectional theories are of further interest to us because they can shed light on why intersectional theory and the idea of multiple differences were so enthusiastically incorporated into contemporary feminist theory. It is intersectionality's versatility - shown by its incorporation into feminist standpoint theory and its later adaptation by feminist postmodernism - that has made this theory so long-lived.

Intersectional theory and feminist postmodernism: Butler as a turning point

The earlier works of feminist and queer philosopher Judith Butler are epitomes of feminist postmodernist thought. Butler (2006) is best known for its deconstruction of the feminist sex/gender distinction and its radical social constructivist ideas about gender as something that now "proves to be performative - that is, constituting the identity it is purported to be" (Butler, 1990/2006: 33). Butler's theory of gender performativity and subversion is based on the postmodern and Foucauldian deconstruction of the Cartesian cogito: the days of the modern rational subject, according to Butler, are gone. There is no longer a "doer behind the deed" (Butler, 1990/2006: 181); instead, "the 'doer' is variably constructed in and through the deed" (Butler, 1990/ 2006: 181). This antifoundationalism is also mirrored in Butler's conceptualization of identity: if the doer, apart from her/his actions, is no longer there, then what are we to do with the category of 'Woman' that has important feminist-political meanings as well? Seen from Butler's antifoundationalist point of view, there is no stable (female) subject position; the feminist assumption that women have a "common identity" (Butler, 1990/2006: 4) is built on the Enlightenment fictions of essentialism and universalism. This complicates the traditional model of feminist identity politics (which rests upon a logic of representationalism, or the idea that there are two different and separate kinds of ontological entities, namely objects and their representations, as we will see later). Butler's complicating move is not only supported by her philosophical antifoundationalism, but by her own take on intersectional theory.

Butler in Gender Trouble already hints at the intersections of gender, 'race'/ethnicity, class, and sexuality, and criticizes the additive approach to these social categories. But her incorporation of intersectional theory only becomes fully manifest in Butler (1993), where she states that she does not want to do away with the categories of gender, 'race,' and others altogether: she may be an antifoundationalist, but is no supporter of what Crenshaw dubbed "the vulgarized social construction thesis" (Crenshaw, 1991: 1296), i.e., the idea that nothing exists outside of its social constructedness. After all, the entire project of Bodies That Matter was to study "[w]hich bodies come to matter - and why?" (Butler, 1993: xii). Maybe more than in Gender Trouble, Butler in Bodies That Matter clarifies that although she believes our identities are socially, discursively, and performatively constructed, these identities and social categories do exist, namely in their corporeal materialization and as the effects of "oppressive regimes of power" (Butler, 1993: 123). Although intersectional theorists may criticize Butler for over-investing in the subversion of power regimes by queering their norms, her approach approximates a typical intersectional one; they would applaud Butler's thesis that neither sexual difference nor 'race' or any other social category trumps others in the constitution of the subject, and in the analysis of how this subject is oppressed (Butler, 1993: 130).

It would be too much to claim that Butler was solely responsible for mainstreaming intersectionality, though she did focus on the intersections of sex, gender, and sexuality in Gender Trouble, and their intersections with 'race' in Bodies That Matter. The popular reception of these books in the feminist theoretical canon has made the subject of intersectionality more accepted. The irony is that although intersectionality has grown into a popular theoretical and multidisciplinary approach in feminist theory, the paradigm itself is now under attack for falling back into the same kind of representationalist logic that was central to identity politics. This is one of intersectionality's most complex and problematic epistemological deficiencies, as we will show next.

\section{Intersectionality's own blind spot: representationalism}

Although feminist postmodernists and intersectional theorists are equally suspicious of the political viability of identity politics - a model that, in the end, rests upon a false universalism - feminist postmodern and poststructuralist thinkers such as Butler have also criticized its epistemology. Whereas Butler argues that the representationalist logic behind identity politics ceased making sense after Foucault showed us that subjects are in fact produced by those discourses and apparatuses of power that represent them, ${ }^{1}$ intersectional theory - before Butler - still appears to be fully embedded in this logic. Intersectional thinkers namely tend to treat subjects such as Black women as being restricted by the hegemonic discourse, though they themselves claim to be able to see through it. Intriguingly, the defective logic that assumes that the (Black) scholar is positioned outside of the discourse is now also being ascribed to Butler by feminist new materialists. In the words of Claire Colebrook:

On the one hand, [...] Butler appears to be anti-postmodern, for she rejects the idea of a system of signs imposed on an otherwise neutral and inaccessible sex. On the other hand, she represents the epitome of equivocal logics. Our position within a system of norms produces a radical difference between norm and that which the norm supposedly orders, organizes and represents (Colebrook, 2004: 293).

What is truly problematic is that such a representationalist or 'equivocal' feminist theory, even according to Butler, runs the risk of being self-defeating:

The suggestion that feminism can seek wider representation for a subject that it itself constructs has the ironic consequence that feminist goals risk failure by refusing to take account of the constitutive powers of their own representational claims (Butler, 1990/2006: 6). 
That Crenshaw-inspired intersectional theory set out to break through 'single-axis' or 'either-or' approaches in court as well as in feminist and anti-racist research practices remains epistemologically valuable. After all, feminist philosophy is based on the insight that substance dualism, or the claim that dichotomous pairs are inherently gendered, is key to the naturalization of women (de Beauvoir, 1949/2010; Lloyd, 1983/1994), just like anti-racist philosophy is based on the insight that substance dualism has naturalized and muted non-white subjects (Zack, 2002). Substance dualism is predicated on subject-object differentiation and hierarchy; it lures us into a situation in which "to be different-from means to be worth-less-than” (Braidotti, 1994/2011: 20). But intersectional theory itself turns out to be a form of representationalism (see also Dolphijn \& van der Tuin, 2013), especially when the latter is formulated as "the belief in the ontological distinction between representations and that which they purport to represent; in particular, that which is represented is held to be independent of all practices of representing" (Barad, 2003: 804). Barad shows how this dualism structuring intersectional theory - representations being active and the represented mute; epistemology preceding and governing ontology - prevents ontological reflection. What Butler shares with intersectional theorists and feminists supporting different identity politics is exactly this dualism or 'equivocal logic.'

Seeing through the alleged radicality of liberation movements and their epistemic twists and attempting to shift instead of reproduce power relations is not new, neither in the context of Black theory nor in the gender theory. Anthony Appiah for instance argued for such shifting in the context of black thought. After reviewing the work of W.E.B. Du Bois in "The Uncompleted Argument," Appiah writes:

In his early work, Du Bois took race for granted and sought to revalue one pole of the opposition of white to black. The received concept is a hierarchy, a vertical structure, and Du Bois wished to rotate the axis, to give race a 'horizontal' reading. Challenge the assumption that there can be an axis, however oriented in the space of values, and the project fails for loss of presuppositions (Appiah, 1985/1986: 36). ${ }^{2}$

The argument here is that the geometry (an 'axiometry') implied in black thought makes it impossible to break out of the chains of dualist structures. First, there is dualism within the realm of representations. The Self/Other dichotomy should not be turned on its axis as this results in standpoint theories re-affirming existing power relations. Second, and simultaneously, dualism is ever-present in representationalism's internal structure in which thought holds priority over being. In the manner of Appiah, gender scholars like Colebrook have argued against a reversal within the equivocal logic (according to which women would be upgraded to the level and realm of men) and for the alternative logic of univocity. Following a univocal logic, thought no longer holds priority over being as we have to ask how it is possible that being is thought, both in scholarship and in the roles and positions that bodies get assigned to in the political-cultural sphere. Colebrook proposes starting from a different question:

[...] from a finite point of consciousness within the world, we see ourselves as subjected to relations (Deleuze, 1992); but if one thinks further, if one strives to think from the point of view of the emergence of relations, one will no longer enslave oneself to constituted terms, such as the gender system, the heterosexual matrix or the framing fantasy. One will ask what life must be such that fantasy is possible: what must the body be such that its relations to other bodies take the form of a sexual narrative? (Colebrook, 2004: 286; emphasis added).

Here we find an instance of the (philosophical) stance that Barad labels as knowing in being or onto-epistemology. It is useful to recall the concept of interference here, introduced by Donna Haraway "to diffract the rays of technoscience so that we get more promising interference patterns on the recording films of our lives and bodies" (Haraway, 1997: 16). It is only through the diffractive lens of interference that we can understand how (power) relations really emerge.

The problem haunting many intersectional theories one which has been addressed in several poststructuralist critiques of representationalism - is that although they consider power structures, they lack a profound analysis of power and its affected subjects. Easy assumptions about the workings of power have guided their epistemologies and affirmed power as a purely restrictive force, leading to the under-theorization of the ambiguity of intersectional subjects' agency ( see also Jaunait \& Chauvin, 2012). Instead of merely focusing on the different matrices of domination as Collins does, educational psychologist Dorthe Staunæs (2003), for instance, tries to both unravel how power structures have co-constructed subjects through categorization and to leave room for the analysis of the counteractions of marginalized subjects. Whereas Collins more or less conceptualized the process of social categorization as an all-imposing process, Staunæs - inspired by the Foucauldian idea that where there is power, there must be resistance - preserves the ambiguous agency of these subjects. Collins, like Crenshaw, refers to the issues of power and agency (see Collins, 1990/ 2009: 292-305 and Crenshaw, 1991: 1297), but both theorists still cling to power as a primarily structural and disciplinary phenomenon. ${ }^{3}$ In addition, their focus on severely marginalized subjects leads to an epistemological problem: the experiences of oppressed subjects who are also partially privileged disappear, which turns intersectional theory into a rather defeatist theory of victimization as we will show next.

The work of political philosopher Wendy Brown is relevant if we want to tackle these epistemological blind spots in an onto-epistemological manner - as we have to in order to arrive at our evaluation. In an essay reflecting on the academic institutionalization of women's studies, Brown observes that the multi-sidedness of power (as in the diversified power of feminist postmodernism) has been obscured in most intersectional theories (Brown, 1997: 87). Following in Foucault's and Butler's footsteps, Brown wishes to reflect on the productive, and not merely the oppressive, role that power has in the constitution of subjects (Brown, 1997: 86). Ontologizing Staunæs' epistemological findings, Brown's critique works on a deeper level: she criticizes the representationalist assumptions of intersectional theories by pointing out that intersectional subjects are marked and constituted by "different mechanisms and sites of power, different discursive formations, [and] different regulatory schemes" (Brown, 1997: 86) and that "these powers of subject formation are not separable in the subject itself" (Brown, 1997: 86). The intersectional subject, 
Brown argues, has to be seen as a complex entity that consists of various entanglements of different social categories, all produced by different, particular sites of power, while any analysis of such a subject should be executed holistically. Brown not only criticizes additive intersectional models; she claims that intersectional analyses in general tend to be self-defeating since they cannot but analyze the intersectional subject in a split manner, falling back into the same bifurcated models they wish to criticize. Coming close to our conceptualization of interference, queer theorist Jasbir Puar pushes her critique of intersectionality even further by claiming that the subject is not merely constituted by various power sites, but is also an embodied, material subject, forever in transformation and becoming. Puar takes her inspiration from Gilles Deleuze and is not interested in how subjects are represented, because the privileging of "naming, visuality, epistemology, representation, and meaning [...]" (Puar, 2007: 215) in these theories does not correspond to what a subject really is, namely an assemblage of "dispersed but mutually implicated and messy networks" (Puar, 2007: 211) of social categories. ${ }^{4}$

This discussion of the epistemological and thus ontological blind spots of intersectional theory allows us to take advantage of Verloo's attempt to undo this (postmodernized) standpoint theory or identity politics by thinking through intersecting axes via a pattern of interference. In Verloo's inaugural lecture, interference is only used metaphorically, which means that her work stays within the representationalist realm; her suggestion is epistemological, not onto-epistemological. Working along the lines of feminist philosopher Rosi Braidotti, for whom feminism ought to be "a labour of creation," (Braidotti and Guild, 1991/1996: 164), we wish to follow up on Puar's recent work by elaborating on Barad's take on interference. Criticism, after all, only stays within the confines of representationalism.

\section{Embracing ontology for intersectionality: interference}

Barad has embraced interference and contributed to the development of an intersectional theory that is not based on an ontology-excluding representationalist epistemology. Towards this end, she has - reminding us of Appiah - delved deeply into the geometrical patterns that govern intersectional theory's epistemological assumptions. Rewriting intersectionality according to what she calls an agential realism, she affirms:

an agential realist notion of dynamics [...] is not marked by an exterior parameter called time, nor does it take place in a container called space, but rather iterative intra-actions are the dynamics through which temporality and spatiality are produced and reconfigured in the (re)making of materialdiscursive boundaries and their constitutive exclusions. Exclusions introduce indeterminacies and open up a space of agency; they are the conditions of possibility of new possibilities (Barad \& DeKoven, 2001: 90).

Barad reworks the axiological parameters of intersectional thinking by rethinking time and space along the lines of the emergence of relations. Whereas intersectionality was developed "as a mutually perpendicular set of axes of identification within which marked bodies can be positioned" (Barad \& DeKoven, 2001: 98), Barad tries to release the possibility of entanglement - a term we already encountered when discussing Brown and Puar. Intersectional theory studies how a person (or a group) is positioned, i.e., marked by multiple categories that are different from the person (or group). As the person (or identity group) can be known through these linguistic categories alone, intersectionality only works with categories that have representational power along predetermined axes of hierarchical power relations (Barad \& DeKoven, 2001: 98). Evoking Verloo, Foucault and Colebrook, and explicitly following up on Haraway, Barad wants to think about (power) relations differently, working with "[s]tructures [that] are constraining and enabling, not determining" (Barad \& DeKoven, 2001: 99). Barad, then, sees how the ontological turn takes us out of the essentialism-constructivism opposition: "The space of possibilities does not represent a fixed event horizon within which the social location of knowers can be mapped, nor a homogenous fixed uniform container of choices" (Barad \& DeKoven, 2001: 103). By allowing for relations to be made and made differently, we no longer assume that a social category or a set of social categories has a decisive and uniform effect (essentialism); nor do we continue to believe in the Butlerian queering of the norm (radical social constructivism). Barad affirms that "structures are themselves material-discursive phenomena which are produced through the intra-action of specific apparatuses of bodily production marked by exclusions" (Barad \& DeKoven, 2001: 95; emphasis in original) - that is, non-exhaustive zones of the production of bodies and meanings. Social categories do not pre-exist as determining structures that map subjects (or rather objects) along single or multiple axes. What we tend to call categories or axes do not work as such. Structures are exclusionary (i.e., they are constraining) and enabling (i.e., they allow for surprises). They are nothing but phenomenal interference patterns that are always on the move.

Conceptualizing structures as interference patterns has farreaching effects. Barad reminds her readers of Leela Fernandes, whose class, gender and community analysis of a Calcutta jute mill suggests a dynamics that "is perhaps more akin to a differential gear assemblage in which the gear operations literally work through one another and yet the uneven distribution of forces results in and is the enabling condition for different potentials and performances among the gears" (Barad \& DeKoven, 2001: 79). The idea that patterns are constantly evolving, and that different patterns intra-act instead of merely interacting with one another (also see Lykke, 2011: 208-209), generating an assemblage that is holistic - i.e., not separable - is one of Barad's onto-epistemological key points. Whereas the concept of interaction stands for a traditional atomist ontology in which subjects (or categories and axes, in epistemology) are seen as agents that exist prior to their actions, this model accentuates that "distinct agencies do not precede, but rather emerge through, their intra-action" (Barad et al., 2007: 33). It is this aspect of intra-action that, together with the interference pattern as such, guides us towards envisioning intersectionality differently.

Two innovative applications of intersectional theory in gender research seem to anticipate Barad's full-blown intersectionality-as-interference. The first is political theorist Rita Dhamoon's “Considerations on Mainstreaming Intersectionality" (Dhamoon, 2011), in which she focuses on her own revised intersectional model: the "matrix of 
meaning-making" (Dhamoon, 2011: 238). Although the model has its roots in both Foucauldian poststructuralist thought and Collins' matrix of domination, Dhamoon reconceptualizes this matrix model in such a way that it could - with some re-adjustments - integrate Barad's onto-epistemology. Dhamoon's matrix namely "serves as a depiction of the movement and refractions among interactions, the relationships among processes and sets of interactions, differing levels or depths of political life, and the large picture in which differences are connected" (Dhamoon, 2011: 238-239). Such a revised intersectional model "reflects the shifting fusions of multilayered and relational differences" (Dhamoon, 2011: 238) and hence seems to address the productive, multi-directional intraaction between all these differences.

But seen through a Baradian lens, it soon becomes clear that Dhamoon's matrix is still stuck in a representationalist logic according to which the aforementioned productive effects can easily be predicted: these effects are never really surprises. Dhamoon's matrix partially breaks through this representationalism of prioritizing thought over being by foregrounding a relational ontology in which processes of subject formation are seen as co-evolving with the subjects they constitute. Yet, although Dhamoon's matrix of meaning-making foregrounds "the shifting, messy, indeterminate, dynamic, and multi-layered movements of difference making" (Dhamoon, 2011: 239), it cannot be pushed to complete indeterminacy - which is central to Baradian interference.

Science studies scholar Ingunn Moser's essay "Sociotechnical Practices and Difference" (Moser, 2006) also comes close to Baradian interference - albeit for different reasons. In Moser's ethnographic essay on disabled people's life-stories, she explicitly uses the concept of interference - by referring to Haraway, who Barad also credits - to see how social differences are always in the making through patterns of interference. Moser pays attention to how the interference patterns of gender, 'race'/ ethnicity, disability, and class can work with or against one another, and hence either intensify or decrease oppression or privilege. Significantly, the article begins with a startling example of Moser, an able-bodied woman, being interpolated by one of her disabled interviewees: "In the twinkling of an eye, with a joking statement, Roger was positioned as the boss, the manager or master of the house passing orders to his subordinates, caregivers, or personal assistants" (Moser, 2006: 544). Moser's point is that the alleged binary opposition between disabled and able-bodied, and the possible subversion of the norm of able-bodiedness in a study that gives a disabled subject agency, can work out differently owing to intersecting categories interfering with one another. Moser does not give Roger agency, as it is Roger (the interviewee) who had already positioned Moser (the interviewer) in a stereotypically feminine role. This may not even be a conscious act on Roger's part as it happens '[i] $\mathrm{n}$ the twinkling of an eye, with a joking statement.' Treating this experience as more insightful than the actual interview - thus moving away from the self-conscious subject position of the ethnographer and doing justice to knowing-in-being - Moser foregrounds the indeterminacy and unpredictability that arise in such a relational ontology of interference patterns. Openness, maybe even chaos, is the result: when one for instance tries to undo certain power relations related to gender, one at the same time runs the risk of enlarging these differences or even creating other difference patterns (see Moser, 2006: 557).

\section{Conclusion: on fire with interference}

The instances of interference our argument built on range from Verloo's hands-on political science model to map the effects of EU policies beyond the perpetual evocation of what Nash has called quintessential intersectional subjects to Barad's plea for an onto-epistemological understanding of the emergence of both hierarchical power relations and relations that are subversive because they cannot be understood along the lines of a restrictive power hierarchy. In-between these extremes we have positioned scholars who seem to approach interference either epistemologically (Dhamoon) or by stumbling upon relationalities that almost suggest pure potentia (Moser). We see this spectrum as fertile ground for undoing some of the intersectional theory's most prominent shortcomings - problems that derive from its buying into representationalism. A more fully worked out 'interference theory' would hence allow gender researchers from many disciplines to produce precise case studies that demonstrate how power (being potestas and potentia) is intrinsically out of phase with itself, and how, therefore, the production of the most surprising interference patterns is inherent to its working. In light of the genealogy of intersectionality, sensitivity for such indeterminacy is what we need to free ourselves from the defeatism as well as the defeat of intersectionality. It is not that intersectional theory has to be set alight; we nevertheless hope that this article has inflamed passions for furthering theory on interference.

\section{Endnotes}

${ }^{1}$ See Butler, 2006/1990: 2-3, and Foucault, 1976/1990: 135-159 for the productive side of power.

${ }^{2}$ Appiah made this point in a section titled 'Concluding Unscientific Postscript'. We read this as a reference to Søren Kierkegaard's eponymous work that not only looks back at his entire oeuvre - like Appiah looks back at Du Bois' oeuvre - but also, and significantly, criticizes Hegel's Master-Slave's dialectics (Kierkegaard, 1846/1941). What we encounter is a critique of conceptualizations of the Self/Other structure that are unable to shift existing power relations.

${ }^{3}$ Note that Crenshaw's conceptualization of power, more than Collins', is already moving in a Foucauldian/Butlerian direction since she thinks it is possible for marginalized subjects to take on their social categorization in a positive, subversive manner. See Crenshaw, 1991: 1297. Yet, Crenshaw still holds onto a group politics model which prevents her from going as far as Foucault and Butler.

${ }^{4}$ See also Puar (2012).

\section{References}

Appiah, A. (1986). The uncompleted argument: Du Bois and the illusion of race. In Henri L. Gates (Ed.), "Race", writing, and difference (pp. 21-37). Chicago and London: The University of Chicago Press (Original work published 1985).

Barad, K., \& DeKoven, M. (2001). Re(Con)figuring space, time, and matter. In M. DeKoven (Ed.), Feminist locations: Global and local, theory and practice (pp. 75-109). New Brunswick: Rutgers University Press.

Barad, K. (2003). Posthumanist performativity: Toward an understanding of how matter comes to matter. Signs: Journal of Women in Culture and Society, 28(3), 801-831.

Barad, K., Beauvoir, Simone de Borde, C., \& Malovany-Chevallier, S. (2007). Meeting the universe halfway: Quantum physics and the entanglement of matter and meaning. Durham - London: Duke University Press. 
Braidotti, R., \& Guild, E. (1996). Patterns of dissonance: A study of women in contemporary philosophy. (E. Guild, Trans.). Cambridge: Polity Press (Original work published 1991).

Braidotti, R. (2011). Nomadic subjects: Embodiment and sexual difference in contemporary feminist theory. New York: Columbia University Press (Original work published 1994).

Brown, W. (1997). The impossibility of women's studies. Differences: A Journal of Feminist Cultural Studies, 9(3), 79-101.

Butler, J. (1993). Bodies That Matter: On the discursive limits of 'sex'. New York - London: Routledge.

Butler, J. (2006). Gender trouble: Feminism and the subversion of identity With an introduction by the author. New York - London: Routledge (Original work published 1990).

Carbin, M., \& Edenheim, S. (2013). The intersectional turn in feminist theory: A dream of a common language? European Journal of Women's Studies, 20(3), 233-248

Cho, S., Crenshaw, K., \& McCall, L. (2013). Toward a field of intersectionality studies: Theory, applications, and praxis. Signs: Journal of Women in Culture and Society, 38(4), 785-810.

Colebrook, C. (2004). Postmodernism is a humanism: Deleuze and equivocity. Women: A Cultural Review, 15(3), 283-307.

Collins, P. H. (2009). Black feminist thought: Knowledge, consciousness, and the politics of empowerment. New York: Routledge (Original work published 1990).

Combahee River Collective (1982). A black feminist statement. In C. Moraga, \& G. Anzaldúa (Eds.), This Bridge Called My Back. Writings by radical women of color (pp. 210-218). Berkeley, CA: Third Woman Press (Original work published 1977).

Crenshaw, K. (1989). Demarginalizing the intersection of race and sex: A black feminist critique of antidiscrimination doctrine, feminist theory and antiracist politics. The University of Chicago Legal Forum (pp. 139-167).

Crenshaw, K. (1991). Mapping the margins: Intersectionality, identity politics, and violence against women of color. Stanford Law Review, 43(6), 1241-1299.

Davis, K. (2008). Intersectionality as buzzword: A sociology of science perspective on what makes a feminist theory successful. Feminist Theory 9(1), 67-85

de Beauvoir, S. (2010). The second sex. (C. Borde \& S. MalovanyChevallier, Trans.). New York: Alfred A. Knopf (Original work published 1949).

Deleuze, Gilles (1992). Expressionism in Philosophy: Spinoza (Martin Joughin Trans.). New York: Zone Books.

Deckha, M. (2008). Intersectionality and posthumanist visions of equality Wisconsin Journal of Law, Gender E Society, 23(2), 249-267.

Dhamoon, R. K. (2011). Considerations on mainstreaming intersectionality. Political Research Quarterly, 64(1), 230-243.

Dolphijn, R., \& van der Tuin, I. (2013). A thousand tiny intersections: Linguisticism, feminism, racism and Deleuzian becomings. In A Saldanha, \& J. M. Adams (Eds.), Deleuze and race (pp. 129-143). Edinburgh: Edinburgh University Press.

Felski, R. (1997). The doxa of difference. Signs: Journal of Women in Culture and Society, 23(1), 1-21.

Foucault, M. (1990). The history of sexuality. Volume 1: An introduction. (R. Hurley, Trans.). New York: Vintage Books (Original work published 1976).

Franken, M., Woodward, A., Cabó, A., \& Bagilhole, B. (Eds.). (2009). Teaching intersectionality: Putting gender at the center. Stockholm: Stockholm University Press.

Haraway, D. J. (1988). Situated knowledges: The science question in feminism and the privilege of partial perspective. Feminist Studies, 14(3), 575-599.

Haraway, D. J. (1997). Modest_Witness@Second_Millennium. FemaleMan@_Meets OncoMouse ${ }^{T M}$ : Feminism and technoscience. New York: Routledge.

Harding, S. (1986). The science question in feminism. Milton Keynes: Open University Press.
Harding, S. (1993). Rethinking standpoint epistemology: What is "strong objectivity"? In L. Alcoff, \& E. Potter (Eds.), Feminist epistemologies (pp. 49-82). New York: Routledge.

Harding, S. (1995). "Strong objectivity": A response to the new objectivity question. Synthese, 104(3), 331-349.

hooks, b. (1984). Feminist theory from margin to center. Boston: South End Press.

Jaunait, A., \& Chauvin, S. (2012). Representing the intersection in France and America: Theories of intersectionality meet social science. Revue Française de Science Politique, 62(1), 5-20 (English-language edition).

Kierkegaard, S. (1941). Concluding unscientific postscript. (Lowrie, Walter \& D.F. Swenson, Trans.). Princeton: Princeton University Press (Original work published 1846).

Lloyd, G. (1994). The man of reason: 'Male' and 'female' in western philosophy. New York: Routledge (Original work published 1983).

Lorde, A., McClintock, A., Mufti, A., \& Shohat, E. (1997). Age, race, class, and sex: Women redefining difference. In A. McClintock, A. Mufti, \& E. Shohat (Eds.), Dangerous Liaisons: Gender, Nation, and Postcolonial Perspectives (pp. 374-380). Minneapolis - London: University of Minnesota Press.

Lutz, H., Theresa Herrera Vivar, M., \& Supik, T. (Eds.). (2011). Framing intersectionality: Debates on a multi-faceted concept in gender studies. Farnham - Burlington: Ashgate.

Lykke, N. (2011). Intersectional analysis: Black box or useful critical feminist thinking technology? In H. Lutz, M. Theresa Herrera Vivar, \& T. Supik (Eds.), Framing Intersectionality: Debates on a Multi-Faceted Concept in Gender Studies (pp. 207-220). Farnham - Burlington: Ashgate.

McCall, L. (2005). The complexity of intersectionality. Signs: Journal of Women in Culture and Society, 30(3), 1171-1800.

Moser, I. (2006). Sociotechnical practices and difference: On the interferences between disability, gender, and class. Science, Technology \& Human Values, 31(5), 537-564.

Mügge, L., \& de Jong, S. (2013). Intersectionalizing European politics: Bridging gender and ethnicity. Politics, Groups and Identities, 1(3), 380-389.

Nash, J. C. (2008). Re-thinking intersectionality. Feminist Review, 89, 1-15.

Oleksy, E. H. (2011). Intersectionality at the cross-roads. Women's Studies International Forum, 34(4), 263-270.

Puar, J. K. (2007). Terrorist assemblages: Homonationalism in queer times. Durham - London: Duke University Press.

Puar, J. K. (2012). "I would rather be a cyborg than a goddess": Becoming-intersectional in assemblage theory. Philosophia, 2(1), 49-66.

Saldanha, A. (2006). Reontologising race: The machinic geography of phenotype. Environment and Planning D: Society and Space, 24(1), 9-24.

Spelman, E. V. (1988). Inessential women: Problems of exclusion in feminist thought. Boston: Beacon Press.

Staunæs, D. (2003). Where have all the subjects gone? Bringing together the concepts of intersectionality and subjectification. NORA: Nordic Journal of Feminist and Gender Research, 11(2), 101-110.

Verloo, M. (2006). Multiple inequalities, intersectionality and the European Union. European Journal of Women's Studies, 13(3), 211-228.

Verloo, M. (2009). Intersectionaliteit en interferentie: Hoe politiek en beleid ongelijkheid behouden, bestrijden en veranderen [Intersectionality and interference: How politics and policies keep, fight, and change inequality]. Inaugural Lecture, Radboud University Nijmegen.

Wekker, G. (2002). Building nests in a windy place: Thinking about gender and ethnicity in the Netherlands. : Inaugural Lecture, Utrecht University.

Wekker, G. (2004). Still crazy after all these years... Feminism for the new millennium. European Journal of Women's Studies, 11(4), 487-500.

Yuval-Davis, N. (1999). What is 'transversal politics'? Soundings Issue, 12, 94-98.

Zack, N. (2002). Philosophy of science and race. New York - London: Routledge.

Zack, N. (2007). Can third wave feminism be inclusive? Intersectionality, its problems, and new directions. In L. Martín Alcoff, \& E. Feder Kittay (Eds.), The Blackwell Guide to Feminist Philosophy (pp. 193-207). Malden Oxford: Blackwell Publishing. 
Erratum

\title{
Erratum to "From intersectionality to interference: Feminist onto-epistemological reflections on the politics of representation" [Women's Studies International Forum, 41 (2013) 171-178]
}

\author{
Evelien Geerts, Iris van der Tuin* \\ Graduate Gender Programme, Utrecht University, The Netherlands
}

The publisher regrets the error in the reference section of this article. For some references the editor names were printed within the author names by mistake. The correct references are provided below and are published as an erratum.

The publisher would like to apologise for any inconvenience caused.

Barad, K. (2001). $\operatorname{Re}($ Con)figuring space, time, and matter. In M. DeKoven (Ed.), Feminist locations: Global and local, theory and practice (pp. 75-109). New Brunswick: Rutgers University Press.

[The in-text citation of the above reference on pages 176 and 177 should read Barad, 2001 instead of Barad \& DeKoven, 2001.]

Barad, K. (2007). Meeting the universe halfway: Quantum physics and the entanglement of matter and meaning. Durham - London: Duke University Press.
[The in-text citation of the above reference on pages 171, 172, and 176 should read Barad, 2007 instead of Barad et al., 2007.]

Braidotti, R. (1996). Patterns of dissonance: A study of women in contemporary philosophy. (E. Guild, Trans.). Cambridge: Polity Press (original work published 1991).

[The in-text citation of the above reference on page 176 should read Braidotti, 1996 instead of Braidotti and Guild, 1996.]

Lorde, A. (1997). Age, race, class, and sex: Women redefining difference. In A. McClintock, A. Mufti, \& E. Shohat (Eds.), Dangerous liaisons: Gender, nation, and postcolonial perspectives (pp. 374-380). Minneapolis - London: University of Minnesota Press.

[The in-text citation of the above reference on page 173 should read Lorde (1997) instead of Lorde et al., 1997.]

DOI of original article: http://dx.doi.org/10.1016/j.wsif.2013.07.013.

* Corresponding author at: Muntstraat 2a, 3512EV Utrecht, The Netherlands.

E-mail address: I.vanderTuin@uu.nl (I. van der Tuin). 